\title{
EDITORIAL
}

\section{Eradicate Social Poverty through Developing Educational Technology}

\author{
Longjun Zhou ${ }^{1,2}$
}

1. Jiangsu Second Normal University, Nanjing 210020, Jiangsu, China

2. Research Scientist, Engineering Research Center of Digital Learning Support Technology, Ministry of Education, Changchun 130000, Jilin, China

"We need technology in every classroom and in every student and teacher's hand, because it is the pen and paper of our time, and it is the lens through which we experience much of our world."

-David Warlick

$\mathrm{P}$ OVERTY is a complex social problem. According to Rowntree (1902) and Reynolds (1971), poverty is a multi-faceted, dynamic, and complex aggregate, which is related to economic, social, cultural and other factors. In the historical process of humankind's continuous struggle with poverty, eliminating various factors that form poverty, especially the ability factors that restrict individual development, including education, health, etc., so as to finally solves the problem of poverty is the ultimate goal of anti-poverty. Among them, education, as a fundamental measure to improve the feasible ability of individuals, is considered to be a key factor in eliminating poverty and promoting social development and progress (Tilak, 2002).

From the perspective of balanced development, each country has a special period of unbalanced educational development among different ethnics, groups, and regions. In order to solve these imbalances, various countries have made effective attempts and achieved great results. Practical experience showed that in underdeveloped countries and regions, more attention was paid to how education could help people get rid of poverty (Schwartzman, 2004; Zhang, 2020; Zhu, 2020), while in developed countries or regions, researchers paid more attention how to help achieve educational equity through

(C) 2021 Insights Publisher. All rights reserved.

cc) (i) (-) Creative Commons Non Commercial CC BY-NC: This article is distributed under the terms of the Creative Commons Attribution-NonCommercial 4.0 License

(http://www.creativecommons.org/licenses/by-nc/4.0/) which permits non-commercial use, reproduction and distribution of the work without further permission provided the original work is attributed by the Insights Publisher. 
inclusive education and promote the balance of development between regions and groups (Gaggioli \& Sannipoli, 2021; Hirsch, 2007).

Among the various elements of educational development, information technology is exerting an unimaginable power. Both developed and developing countries and regions are beginning to attach importance to the education information and integrate educational technology into national development strategies (Li et al., 2021; Machekhina, 2017). This move is aimed at expanding the coverage of high-quality educational resources and the balanced development of education by adopting practical measures and approaches such as the sharing and co-construction of high-quality resources, mutual training of regional teachers, and personalized resource distribution through the coupling effect of information technology and education, so as to achieve eventual fairness in education quality (Cheng \& Haiyan, 2016).

The three articles published in this issue of SIEF include "Research on the Targeted Poverty Alleviation Model of China's Online Education Based on "Three Classrooms-Taking the Shishi Xiangyun Online School in Cheng$d u$, China as an Example" (Tian et al., 2021), "Using Information Technology to Promote Education The improvement of education quality in resourcepoor areas-Taking Qianxinan Prefecture, Guizhou Province, China as a sample (Huang, 2021) and "Investigating the Impact of Literacy-infused Science Intervention on Economically Challenged Students' Science Achievement: A Case Study from a Rural District in Texas" (Irby, 2021), come from areas with superior educational resources and weak areas in developing countries, and rural areas in developed countries where high-quality educational resources are relatively scarce. The authors of the three articles explained how technology can be used in educational development from different perspectives.

We can see from these three articles that the rapid development of information technology provides new ideas and methods for solving the problem of unbalanced education development. It allows developed countries and regions to realize the widespread dissemination of high-quality educational resources through technology, and provides support for the use of information products and information technology in poor areas. Underdeveloped countries and regions use educational technology to share high-quality resources with developed countries and regions, and effectively improve the level of teachers and teaching quality, so that students receive good education. Technology rooted in education provides a practical and effective path for narrowing the gap between urban and rural education development and ultimately achieving targeted poverty alleviation through education. 


\section{References}

Cazes, B. (1973). Lloyd G. Reynolds, The Three Worlds of Economics, Yale University Press, 1971, pp344. Annales. Histoire, Sciences Sociales, 28(5):1216-1216. DOI: https://doi.org/10.1017/S0395264900165965

Cheng, S., \& Haiyan, L. (2016, March). Digital Education Resource Configuration Mode Transformation-From the Co-construction and Sharing to the Public to be Shared. In 2016 Eighth International Conference on Measuring Technology and Mechatronics Automation (ICMTMA ) (pp227-pp230). IEEE. DOI:

https://doi.org/10.1109/ICMTMA.2016.64

Gaggioli C., \& Sannipoli M. (2021). Improving the Training of Support Teachers in Italy: The Results of a Research on Attitudes Aimed at Students with Intellectual Disabilities. Science Insights Education Frontiers, 8(2):1037-1057. DOI https://doi.org/10.15354/sief.21.or021

Hirsch E. D. (2007). The Knowledge Deficit: Closing the Shocking Education Gap for American Children. Houghton Mifflin Harcourt.

Huang, J. (2021). Using information technology to improve the quality of education in areas lacking educational resources: Taking Southwestern Guizhou prefecture in Guizhou, China as a sample. Science Insights Education Frontiers, 9(1):1199-1212. DOI: https://doi.org/10.15354/sief.21.re039

Irby, B.J., Tong, F., Lara-Alecio, R., Tang, S., Guerrero, C., Wang, Z., \& Zhen, F. (2021). Investigating the impact of literacy-infused science intervention on economically challenged students' science achievement: A case study from a rural district in Texas. Science Insights Education Frontiers, 9(1):1123-1141. DOI:

https://doi.org/10.15354/sief.21.or033

Li, J., Wan, Q., Lu, X., Yang, L., \& Zeng, H. (2021). The development direction and suggestion of modernized education informatization-policy thinking triggered by "China Education Modernization 2035". Distance Education in China (4):21-30. [Chinese] DOI: https://doi.org/10.13541/j.cnki.chinade.2021.04.003

Machekhina, O. N. (2017). Digitalization of education as a trend of its modernization and reforming. Revista Espacios, 38(40):26. http://www.revistaespacios.com/a17v38n40/17384026.html

Rowntree, B.S. (1902) Poverty: A Study of Town Life. London: Macmillan Policy Press.

Schwartzman, S. (2004). Equity, quality, and relevance in higher education in Brazil. Anais da Academia Brasileira de Ciências, 76(1):173-188. DOI: https://doi.org/10.1590/S0001-37652004000100015 
Tian, J., Mao, W., Liao, L. \& Zhou, X. (2021). Targeted poverty alleviation model of China's online education based on "Triple Classroom": Take the "Shi Shi Xiang Yun" online school in Chengdu, China as an example. Science Insights Education Frontiers, 9(1):1183-1197. DOI: https://doi.org/10.15354/sief.21.re035

Tilak, J.B. (2002). Education and poverty. Journal of Human Development, 3(2):191-207. DOI: https://doi.org/10.1080/14649880220147301

Zhang, L. (2020) Overview of the poverty-alleviation by supporting education in China. Science Insights Education Frontiers, 6(2):631-651. DOI: $\underline{\text { htps://doi.org/10.15354/sief.20.re010 }}$

Zhu, H. (2020). Hope for girls' education in poverty-stricken areas: the school-running experience and process of Huaping Girls' High School in Yunnan, China. Science Insights Education Frontiers, 6(2):653-667. DOI: https://doi.org/10.15354/sief.20.or035

Correspondence to: Longjun Zhou, Ph.D. Jiangsu Second Normal University Nanjing 211200, Jiangsu 